\title{
Quality of life in postlingual geriatric adult cochlear implant users
}

\section{Postlingual geriatrik koklear implant kullanıcılarında yaşam kalitesi}

\author{
Sukru TURAN ${ }^{1 *} \square$, Birgul GUMUS² $\square$, Ercan KAYA² $\square$, Mehmet Ozgur PINARBASLI² $\square$, \\ Melek Kezban GURBUZ² $\square$, Saziye Armagan INCESULU² $\square$
}

${ }^{1}$ Corum Sungurlu State Hospital, Departmant of otolaryngology head and neck surgery Corum/TURKEY ${ }^{2}$ Osmangazi University, Faculty of medicine, Departmant of otolaryngology head and neck surgery, Eskisehir/TURKEY

\begin{abstract}
Aim: Sensorineural hearing losses in adults may prevent communication with the environment, leading to social isolation, mental problems, loss of business and a reduced quality of life. Cochlear implantation is an important treatment method enabling restoration of hearing in selected patients who have postlingual severe hearing loss and fail to benefit from hearing aids. In this study, we aimed to research the effect of cochlear implant on the quality of life of geriatric patients aged 60 and over with post lingual hearing loss, who underwent unilateral cochlear implantation due to severe and profound sensorineural hearing loss.
\end{abstract}

Materials and Method: 17 geriatric post lingual patients aged 60 and older who underwent unilateral cochlear implantation due to severe and profound sensorineural hearing loss between 2008 and 2015 were included in this study. A Turkish language version of the Short-Form 36 survey was used to evaluate the patient's quality of life.

Results: The patients were aged between 61 and 84 years, and the mean age of the patients was $69,5 \pm 7$ years. The etiology of hearing loss included sudden hearing loss 6 patients, progressive hearing loss in 10 patients, and a sequel of meningitis in 1 patient. According to the result of the Short-Form 36 survey, physical condition, general condition, and psychological condition results were found to be positive at the rates of $76,4 \%, 88,2 \%$, and $94,1 \%$ respectively.

Conclusion: In selected patients of advanced age, cochlear implantation is a treatment method that improves, aside from hearing rehabilitation, the patients' relationship with the environment, eliminating the need for additional care and support, contributing to increased self-confidence and emotional happiness, and consequently, positively affecting the quality of life.

Keywords: Cochlear implant; geriatric cochlear implant; hearing loss; quality of life 


\section{öz}

Amaç: Sensörinöral tip işitme kayıpları erişkinlerde, çevre ile iletişimi engelleyerek sosyal izolasyona, ruhsal problemlere, iş kaybına ve düşük yaşam kalitesine neden olabilir. Koklear implantasyon post-lingual ileri derecede işitme kaybı olan ve işitme cihazlarından fayda görmeyen seçilmiş vakalarda işitmenin restorasyonunu sağlayan önemli bir tedavi yöntemidir. Bu çalışmada ileri ve çok ileri derecede sensörinöral tip işitme kaybı nedeniyle tek tarafı koklear implant operasyonu yapılan, post lingual işitme kayıplı 60 yaş ve üzerindeki geriatrik hastalarda koklear implantın yaşam kalitesi üzerine etkisini araştırmayı amaçladık.

Gereç ve Yöntemler: Çalışmaya 2008 ve 2015 yılları arasında ileri ve çok ileri derecede sensörinöral tip işitme kaybı nedeniyle tek taraflı koklear implant operasyonu yapılan, 60 yaş ve üzerinde 17 geriatrik post-lingual olgu dahil edildi. Olguların yaşam kalitesini değerlendirmek için Short Form -36 anketinin Türkçe versiyonu kullanıldı.

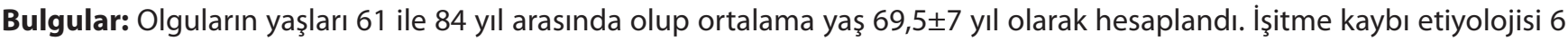
olguda ani işitme kaybı, 10 olguda progresif işitme kaybı, 1 olguda ise menenjit sekeli olarak tespit edildi. Short Form-36 anket sonucuna göre; fiziksel durum sonuçları $\% 76.4$, genel durum sonuçları $\% 88.2$, psikolojik durum sonuçları ise $\% 94.1$ oranlarında olumlu olarak bulundu.

Sonuç: Illeri yaşta seçilmiş hastalarda koklear implantasyon, işitme rehabilitasyonunun yanında, hastanın çevresi ile ilişkilerini geliştiren, ek bakım ve destekten kurtulmasını sağlayan, kendine güveni ve duygusal olarak mutluluğunun artmasına katkıda bulunan; sonuç olarak yaşam kalitesini olumlu yönde etkileyen bir tedavi metodudur.

Anahtar Sözcükler: Koklear implant, geriatrik koklear implant; işitme kaybı; yaşam kalitesi

\section{Introduction}

Sensorineural hearing losses in adults may prevent communication with the environment, leading to social isolation, mental problems, loss of business, cognitive disorders and a reduced quality of life. The effects of hearing loss cited above varies according to the degree, type and onset age of hearing loss. In 2016, the prevalence of hearing loss in our country was 5.4\% in individuals aged 55-64 years, $15 \%$ in patients aged $65-74$ years, and higher in individuals aged above 75 years, and $34.7 \%$ of the individuals in this age group suffered from different degrees of hearing loss [1].

Cochlear implantation is able to help achieve restoration of hearing in selected patients who have severe/profound sensorineural hearing loss and fail to benefit from hearing aids [2]. The recent developments have served to enhance its performance. Psychosocial factors should also be evaluated along with the audiologic factors in the success of cochlear implants. Physical conditions, independence, social relations and psychological conditions of individuals also affect the quality of life [3,4]. In addition to the objective gains, the benefits subjectively felt by the individual are also quite important in presenting the results derived from cochlear implant [2].

In this study, we aimed to research the effect of cochlear implant on the quality of life of geriatric patients in our centre aged 60 and older with post lingual hearing loss, who underwent unilateral cochlear implantation due to severe and profound sensorineural hearing loss.

\section{Materials and Method}

17 geriatric post lingual patients aged 60 and older who underwent unilateral cochlear implantation due to severe and profound sensorineural hearing loss at Otorhinolaryngology department of Eskişehir Osmangazi Faculty between 2008 and 2015 were included in this study. Approval was obtained from Eskişehir Osmangazi University Clinical Researches Ethics Committee under the protocol number $80558721 / 176$ for this study. All patients who regularly appeared for annual checks after the operation were informed about the study, and informed consents were taken. The chronological age of the patients, the age at the date of cochlear implantation, gender, complaints at admission to our clinic, etiology of hearing loss, hearing loss onset age, severe hearing loss onset age, duration of hearing aid use, and educational status of the patients were inquired. A detailed ear nose and throat examination of the patients and audiologic tests were performed. Inquiries on the quality of life can be done with open-ended and closedended questions. In this study, a closed-ended questionnaire was preferred because the results could be standardised, and questions could be easily answered by patients with different socioeconomic backgrounds. A Turkish language version of 
the Short-Form 36 (SF-36) survey was used to evaluate the patients' quality of life. SF-36 is a widely used survey consisting of 36 questions in respect of which validation, reliability and norm studies with respect of its Turkish language version were performed in our country. For evaluating the survey easily, the questions were divided into 3 main groups including 8 questions on general condition, 16 questions on physical condition, and 12 questions on psychological condition. The answer choices to all questions were replaced by an visual anologue scale (VAS), an easier to answer and computable scale, consisting of a 100-mm straight line. Answers above $50 \mathrm{~mm}$ were considered significant. The patients were interviewed face-to-face and the survey was explained to the patients in detail by the Audiologist. The patients were asked to answer the questions in the survey considering their own condition. Illiterate patients were asked to fill the survey with the help of their relatives. The patients were asked to answer the questions in the SF-36 survey by comparing their condition prior to cochlear implant with their condition after cochlear implant surgery.

\section{Results}

The patients were aged between 61 and 84 years, and the mean age of the patients was $69.5 \pm 7$ years. The surgery age of the patients was between 60 and 81 years, and the mean surgery age was $67 \pm 7.1$ years. The postoperative follow-up period was 6 to 105 months, with the mean follow-up period being $37.4 \pm 31.6$ months. Four patients $(23.5 \%)$ were female and 13 patients $(76.5 \%)$ were male. The etiology of hearing loss included sudden hearing loss 6 patients, progressive hearing loss in 10 patients, and a sequel of meningitis in 1 patient. The cochlear implant was placed in the left ear in 10 patients and in the right ear in 7 patients. The cochlear implant brands were Nucleus in 6 patients, Advanced Bionics in 5 patients, Medel in 4 patients and Oticon in 2 patients. When educational levels of the patients are concerned, 7 patients had a high school degree, 6 patients had a primary school degree, 2 patients had an undergraduate degree, and 2 patients did not have a reading and writing education at all. The onset of hearing loss in 8 patients occurred in childhood, and the age values are unknown. The other 9 patients had onset of hearing loss between 33 and 57 years of age, and the mean age was $46.2 \pm 8.4$ years. The age of onset of severe hearing loss of seventeen patients was between 42 and 73 years, and the mean age was $54.5 \pm 8$ years. The duration of hearing aid use was between 2 and 25 years and the mean duration of hearing aid use was $13.6 \pm 9.3$ years. 10 (90.9\%) of the 11 patients who had tinnitus complaints before the operation experienced a regression of the complaint in the postoperative period. In the preoperative period, 2 patients with intermittent dizziness developed transient dizziness in the postoperative period. In other patients, no complaints and complications were observed in the postoperative period. The Pure Tone Average of the patients with a hearing aid was between 30 and 50 decibels $(\mathrm{dB})$ and the mean value was $37.5 \pm 5.9 \mathrm{~dB}$. The Speech Reception Threshold of the patients with a hearing aid was between 30 and $45 \mathrm{~dB}$ and the mean value was $36.6 \pm 5.7 \mathrm{~dB}$. The Speech Discrimination values of the patients were between $64 \%$ and $36 \%$ and the mean value was calculated as $54.6 \pm 8.8 \%$. According to the result of the SF-36 survey, physical condition, general condition, and psychological condition results were found to be positive at the rates of $76,4 \%, 88,2 \%$, and $94,1 \%$, respectively.

\section{Discussion}

Hearing loss can be caused by damage to any portion of the peripheral and central auditory systems. The main causes of sensorineural hearing loss are degenerative processes associated with aging, genetic mutations, noise exposure, exposure to therapeutic drugs that have ototoxic side effects, and chronic conditions [5]. In their study on 68 patients with cochlear implants over 60 years of age, Huarte et al. found progressive hearing loss in 57 cases (83.8\%) and sudden hearing loss in 11 cases (16.2\%). In our study, the etiology of hearing loss included progressive hearing loss in 10 cases (58.8\%), sudden hearing loss in 6 cases (35.5\%), and a sequel of meningitis in 1 patient (5.9\%) [6].

Severe hearing loss that develops in old age is a health problem that negatively affects the communication with the environment, which from time to time, leads to social isolation [7]. This is not only a personal problem, but also a factor that negatively affects the close environment of the person. Most of the time, the main cause is presbycusis, and hearing loss due to presbycusis can usually be rehabilitated with the appropriate hearing aid. Today, cochlear implantation is an alternative treatment method in elderly patients who cannot be rehabilitated with digital hearing aids [7]. However, the benefits to be obtained from cochlear implant are negatively affected by the fact that the duration of hearing loss in elderly patients is very long and the patient has accompanying perception and cognitive problems $[8,9]$. In addition, the success of cochlear implantation is strongly correlated with hearing loss onset age, hearing-loss duration, etiologic cause, residual hearing value and use of hearing aids and $[2,10]$. 
With the use of cochlear implants becoming widespread, the studies on quality of life have increased [11]. The World Health Organization defines quality of life as "an individual's perception of their position in life in the context of the culture and value systems in which they live and in relation to their goals, expectations, standards and concerns (current approach) [12]. The effect of the cochlear implant on a person's daily life can be understood by evaluating the quality of life. Surveys are the most common method used to determine the quality of life of adults. In a study with 68 patients with cochlear implants over 60 years of age with an average age of 69.2 years, Huarte et al. [6] reported that most of the cases benefited from cochlear implant. In a study with 20 patients with cochlear implants over 70 years of age, Olze et al. [8] found that cochlear implant achieved very successful hearing rehabilitation and reported significant improvement in the quality of life of geriatric patients. In a study with 20 geriatric patients with cochlear implants with a mean age of 72 years; Walter et al. [10] found a dramatic increase in speech performance and quality of life of the patients. In our study where the mean age of the patients was $69.5 \pm 7$ years, it was found that the patients experienced a significant increase in the quality of life in consistency with the literature.

Studies comparing old and young cochlear implant users show that speech perception and auditory skills are similar, and that the discomfort and stress caused by tinnitus improve at the same rate in both groups $[8,9,13,14]$. In our study, preoperative tinnitus complaint diagnosed in 11 patients regressed in 10 of them in the postoperative period. We believe that aside from the benefits of cochlear implant such as the recovery of hearing function and recovery from social isolation, the significant reduction of tinnitus is another factor that improves the quality of life in elderly patients.

\section{Conclusion}

Cochlear implantation in selected patients of advanced age is a treatment method that improves, aside from hearing rehabilitation, the patient's relationship with the environment, eliminating the need for additional care and support, contributing to increased self-confidence and emotional happiness, and in short, positively affecting the quality of life, and yielding promising results.

\section{Declaration of conflict of interest}

The authors received no financial support for the research and/or authorship of this article. There is no conflict of interest

\section{References}

1. Başara BB, Güler C, Çağlar is et al. Republic of Turkey ministry of health health statistics yearbook 2016 Ankara, Turkey: SBSAGEM 2017: 44

2. İncesulu A, Kocatürk S, Kurukahvecioğlu S, et al. Erişkin hastalarda kohlear implantasyon ve yaşam kalitesi. Otoskop, 2001; 3: 127-40.

3. WHO QOL Group Measuring Quality of Life: The Development of the World Health Organization Quality of Life Instrument (WHOQOL), Geneva: WHO.2 Study protocol for the World Health Organization project to develop a Quality of Life assessment instrument (WHOQOL). Qual Life Res 1993; 2. 153-9.

4. Akdoğan Ö, Özcan İ, Özdoğan F, et al. Postlingual İşitme Kayıplı Hastalarda Koklear İmplant Sonrası Hayat Kalitesi. KBB-Forum 2007; 6: 138-40.

5. Cunningham LL, Tucci DL. Hearing Loss in Adults. N Engl J Med. $2017 ; 377: 2465-73$

6. Huarte A, Lezaun R, Manrique M. Quality of life outcomes for cochlear implantation in the elderly. Audiol Neurotol 2014; 19:36-9.

7. Olgun L. İleri Yaşta Koklear İmplantasyon. Turkiye Klinikleri Journal of ENT Special Topics 2012; 5: 25-6.

8. Olze H, Gräbel S, Förster U et al. Elderly patients benefit from cochlear implantation regarding auditory rehabilitation, quality of life, tinnitus, and stress. Laryngoscope, 2012; 122: 196-203.

9. Friedland DR, Runge-Samuelson $\mathrm{C}$, Baig $\mathrm{H}$ et al. Case-control analysis of cochlear implant performance in elderly patients. Arch Otolaryngol Head Neck Surg 2010; 136: 432-8.

10. Di Nardo W, Anzivino R, Giannantonio S, et al. The effects of cochlear implantation on quality of life in the elderly. Eur Arch Otorhinolaryngol 2014; 271: 65-73.

11. Derinsu U. Quality of life in adults with cochlear implant. Curr Pract ORL, 2015; 11: 276-8

12. Zwolan TA, Kileny PR, Telian SA. Self-report of cochlear implant use and satisfaction by prelingually deafened adults. Ear and hearing, $17.3: 198-210$.

13. Budenz CL, Cosetti MK, Coelho DH, et al. The effects of cochlear implantation on speech perception in older adults. J Am Geriatr Soc, $2011 ; 59: 446-53$.

14. Poissant SF, Beaudoin F, Huang J et al. Impact of cochlear implantation on speech unders tanding, depression, and loneliness in the elderly. J Otolaryngol Head Neck Surg 2008; 37: 488-94. 